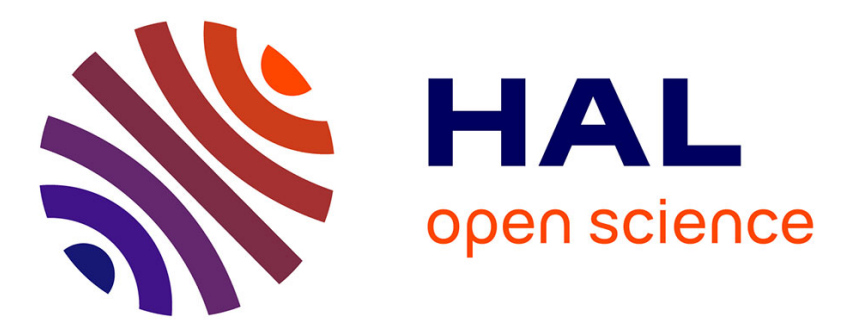

\title{
Long-term Prognostic Impact of Physical Activity in Patients With Stable Coronary Heart Disease
}

Frédéric Bouisset, Jean-Bernard Ruidavets, Vanina Bongard, Dorota. Taraszkiewicz, Emilie Bérard, Michel Galinier, Didier Carrié, Meyer Elbaz, Jean Ferrières

\section{To cite this version:}

Frédéric Bouisset, Jean-Bernard Ruidavets, Vanina Bongard, Dorota. Taraszkiewicz, Emilie Bérard, et al.. Long-term Prognostic Impact of Physical Activity in Patients With Stable Coronary Heart Disease. American Journal of Cardiology, 2020, 125, pp.176 - 181. 10.1016/j.amjcard.2019.10.017. hal-03488362

\section{HAL Id: hal-03488362 https://hal.science/hal-03488362}

Submitted on 21 Dec 2021

HAL is a multi-disciplinary open access archive for the deposit and dissemination of scientific research documents, whether they are published or not. The documents may come from teaching and research institutions in France or abroad, or from public or private research centers.
L'archive ouverte pluridisciplinaire HAL, est destinée au dépôt et à la diffusion de documents scientifiques de niveau recherche, publiés ou non, émanant des établissements d'enseignement et de recherche français ou étrangers, des laboratoires publics ou privés.

\section{다)(1) $(5$}

Distributed under a Creative Commons Attribution - NonCommerciall 4.0 International 


\section{Long-term Prognostic Impact of Physical Activity in Patients with Stable Coronary} Heart Disease

\section{Running Tittle: Physical activity benefits in stable coronary heart disease}

\section{Authors and affiliations:}

Frédéric Bouisset, MDa,b, Jean-Bernard Ruidavets, $\mathrm{MD}^{\mathrm{b}}$ Vanina Bongard, $\mathrm{MD}, \mathrm{PhD}^{\mathrm{a}, \mathrm{b}}$ Dorota. Taraszkiewicz, MDa Emilie Bérard, MD ${ }^{b}$ Michel Galinier, MD, PhDa Didier Carrié, MD, PhDa, Meyer Elbaz MD, $\mathrm{PhD}^{\mathrm{a}}$, and Jean Ferrières, $\mathrm{MD}, \mathrm{PhD}^{\mathrm{a}, \mathrm{b}}$ a - Department of Cardiology, Rangueil University Hospital, Toulouse, France b - Department of epidemiology, INSERM UMR 1027, Toulouse, France

Classification: Original Research Article

\section{Sources of funding:}

The GENES study was supported by grants from Toulouse University Hospital (AOL-99-13L, DRC), INSERM, the Fédération Française de Cardiologie and the Fondation de France.

The sponsor had no role in study design, nor in the collection, analysis and interpretation of data, nor in writing the report and in the decision to submit the article for publication

\section{Corresponding author:}

Dr BOUISSET Frederic , MD

Department of Cardiology

Toulouse University Hospital

1 , avenue Jean Poulhès,

TSA 50032,

31059 Toulouse Cedex 9

France

Email: bouisset.f@chu-toulouse.fr

Tel: + 330561322110

Fax: + 330561323318 


\section{Abstract}

Stable coronary heart disease (CHD) patients are advised to practice regular physical activity (PA). However, data on very long-term prognosis impact of regular exercise remain scarce. We aimed to evaluate the impact of physical activity level on mortality at long term in stable CHD patients. We analyzed 822 patients with stable CHD. They answered questionnaires on medical history, underwent a standardized clinical examination, and provided a fasting blood sample. PA was evaluated by the MOSPA questionnaire. Three tertiles of patients were individualized according to PA level: 0.0-9 Metabolic Equivalent of Task (METs) hour per week ( $n=267)$; 10-39.9 METs hour per week $(n=279)$; and $\geq 40$ METs hour per week $(\mathrm{n}=276)$. After a median follow-up of 14.6 years, 324 patients had died. In a multivariate analysis adjusted for age, dyslipidemia, smoking status, diabetes, high blood pressure, waist circumference, left ventricular ejection fraction, Gensini score, heart rate, ankle-brachial index and duration of disease, physical activity was significantly and independently associated with all-cause mortality. Compared to the lowest PA tertile, both the median and the highest PA tertiles, were associated to a reduction of all-cause mortality risk with HR at $0.79(95 \% \mathrm{Cl}$ [0.61:1.03], $\mathrm{p}=0.08)$ and 0.71 ([0.53:0.96], $\mathrm{p}=0.025)$ respectively; $\mathrm{p}$ for trend $=0.02$. Adjusted HR for an increase of 10 METs hour per week was 0.95 [0.92-0.98], $(p<0.002)$. In conclusion, our study demonstrates an independent association between PA and long term vital prognosis with a 5\% total mortality decrease for an increase of 10 METs hour per week.

\section{Keywords: Coronary Heart Disease; Prognosis; Physical activity}


Current European guidelines for management of stable Coronary Heart Disease (CHD) patients recommend to practice a regular physical activity consisting of $30 \mathrm{~min}$ of moderateto-vigorous intensity aerobic exercising, at least 3 times a week(1). American guidelines encourage CHD patients to practice 150 min per week of moderate intensity exercising, both for primary and secondary prevention $(2,3)$. Moreover, physical activity is part of cardiac rehabilitation programs which are demonstrated to reduce cardiovascular mortality and hospital admission in CHD patients $(4,5)$. However, although numerous publications focused on prognosis impact of physical activity in CHD patients, no study in the literature demonstrates the relation between physical activity level - assessed quantitatively by a validated method - and mortality, after complete adjustment on potential confounding factors in CHD on a very long term follow-up. We sought to analyze the relation between the level of physical activity, assessed by the MOSPA questionnaire, and long term all-cause mortality in a cohort of patients with known stable Coronary Heart Disease.

\section{Methods}

The Genetique et ENvironnement en Europe du Sud (GENES) study was designed to assess the role of gene-environment interactions in the occurrence of $\mathrm{CHD}(6-12)$. From 2001 to 2004 , we prospectively recruited in this study 834 male patients aged between 45 and 74 , living in the Toulouse area (South-western France), admitted in the Department of Cardiology of Toulouse University Hospital, and referred for evaluation and management of their stable CHD. Stable CHD was defined by a previous history of acute coronary syndrome, a previous history of coronary revascularization, a documented myocardial ischemia, a stable angina or the presence of a coronary stenosis of $50 \%$ or more at the coronary angiography. Patients who had presented an acute coronary episode during the past seven days were not included in the study, as they were considered as not stable. Those with a previous history of cancer were not included, as their life expectancy was potentially reduced due to their neoplasm. 
The study protocol was approved by the local ethics committee (file \# 1-99-48, 22/02/2000), in agreement with the French law on human biomedical research and the Declaration of Helsinki. All participants signed an informed consent attesting that they received all the information they needed about the study and that they agreed to participate.

Vital status (and date of death when applicable) was obtained on December $31^{\text {st }}$, 2017 for each participant through the French national database recording all deaths occurring in the French population. Our endpoint was all-cause mortality. Variables were collected through standardized face-to-face interviews and also checked in the patients' medical files. A physical examination was performed by a single physician using standard measurement methods.

Patients were considered as diabetics if they took oral antidiabetic drugs and/or insulin or if their blood glucose level was equal to or higher than $7 \mathrm{mmol} / \mathrm{L}(126 \mathrm{mg} / \mathrm{dL})$. They were considered as having dyslipidemia if they took a lipid-lowering treatment or if LDLcholesterol was $4.1 \mathrm{mmol} / \mathrm{L}(160 \mathrm{mg} / \mathrm{dL})$ or above. Renal function was assessed using the Cockcroft and Gault formula. Severe chronic renal failure was defined by a glomerular filtration rate lower than $30 \mathrm{ml} / \mathrm{min}$. Left Ventricular Ejection Fraction (LVEF) was assessed by ventriculography or by isotopic method or echocardiography when ventriculographic measurements were lacking. All patients underwent a coronary angiography. Coronary stenosis of $50 \%$ or more was considered significant. Diffusion of coronary heart disease lesions was assessed by calculating the Gensini Score (13). Detailed baseline assessment of net energy expenditure in relation with work, commuting and leisure time physical activity in the preceding year, according to category of activity, was obtained by the MONICA Optional Study of Physical Activity questionnaire, (MOSPA questionnaire) $(14,15)$. The MOSPA questionnaire is divided up into four activity categories: occupational, travel to work, household, and leisure-time physical activity. It aims to take in consideration the whole energy expenditure of the subject. Physical activity was expressed in weekly metabolic equivalent scores (MET) hour per week and for the present analysis, physical activity was 
graduated in tertiles and our cohort was thus divided into three groups. All the data detailed above were collected at baseline only.

Statistical analysis was performed on STATA statistical software, release 14.1 (Stata Corporation, College Station, Texas, USA). Continuous variables were summarized as means and standard deviations. Categorical variables are presented as proportions. In univariate analysis, categorical variables were compared with Chi2-test (or Fischer's exact test when necessary). ANOVA were used to compare the distribution of continuous normally distributed data according to tertiles of physical activity. Kruskal-Wallis tests (or logarithmic transformation of the variable when necessary) were used when distribution departed from normality, or when homoscedasticity was rejected. A p-value $<0.05$ was considered statistically significant.

Cumulative survival of patients was determined by the Kaplan-Meier method and compared using the Log-rank test. Univariate and multivariate Cox regression models were used to investigate the association between variables and mortality during the follow-up and to determine hazard ratios $(\mathrm{HR})$ for mortality and $95 \%$ confidence intervals $(95 \% \mathrm{Cl})$. Regression analyses were performed with polynomial models (quadratic and cubic) to examine for possible non-linear relationships between continuous variables (especially physical activity) and mortality. All variables associated with a $p$-value $<0.20$ in univariate analysis were introduced in a multivariate Cox model. A backward procedure was applied to assess variables that were significantly and independently associated with mortality ( $p$-value $<$ 0.05). However, cardiovascular risk factors (High Blood Pressure, diabetes, and dyslipidemia) were kept in the multivariate Cox analysis even if they were not significantly associated with mortality, given that these variables are well described prognostic factors in the literature. The proportional-hazard assumption was tested for each covariate by the "loglog" method, plotting $(-\ln [-\ln ($ survival)]) for each category of a nominal covariate, versus In(analysis time). None of the assumptions could be rejected. 


\section{Results}

We prospectively included 834 men aged 45 to 74 years presenting with stable CHD. Final analysis was performed in 822 subjects with complete data. Vital status was obtained on December 31, 2017 for all patients. During the follow-up period, 324 patients died (39.4\%). The median follow-up was 14.6 years. The 822 patients were divided in three tertile according to their level of physical activity. First tertile ranged from 0 to 9.9 METs hour per week, second from 10 to 39.9 METs hour per week and the third included patients with physical activity superior or equal to 40 METs hour per week. The baseline patients' characteristics according to their physical activity are listed in Table 1. At the end of the follow-up period, mortality rate was $46.1 \%$ in the lowest tertile, $23.4 \%$ in the median and $17.6 \%$ in the highest (log rank test, $\mathrm{p}<0.001$ ). The Kaplan-Meier survival curves, according to physical activity, are presented in Figure a. No interaction exists between physical activity and LVEF, however, we show for illustrative purpose in Figure $\mathbf{b}$ the association between allcause mortality and level of physical activity. In the multivariate analysis, the Cox proportional hazard model was adjusted for age, dyslipidemia, smoking status, diabetes, high blood pressure, total cholesterol, waist circumference, left ventricular ejection fraction, Gensini score, heart rate, ankle-brachial index and duration of disease. Physical activity remained significantly and independently associated with a significant decrease in the risk of all-cause death. Compared to the first tertile (0 to 9.9 METs hour per week), both the second tertile (10 to 39.9 METs hour per week) and the third tertile (>40 METs hour per week) were associated to a reduction of all-cause mortality risk with $\mathrm{HR}$ at $0.79(95 \% \mathrm{Cl}[0.61: 1.03]$, $\mathrm{p}=0.08$ ) and 0.71 ([0.53:0.96], $\mathrm{p}=0.025)$ respectively; $\mathrm{p}$ for trend $=0.02$ (Table 2). Adjusted hazard ratio for an increase of 10 METs hour per week was 0.95 [0.92-0.98], $(p<0.002)$. The others independent predictors of all-cause mortality in our cohort were: age, waist circumference, heart rate, tobacco status, length of disease, ankle brachial index, LVEF, diabetes and dyslipidemia (table 3).

\section{Discussion}


In this study, based on a cohort of stable male CHD patients, we demonstrate the independent association between long term all-cause mortality and self-reported physical activity level assessed at inclusion by the MOSPA questionnaire.

Previous studies have addressed the issue of the impact of physical activity on stable CHD patients survival. In 2000, Wannamethee et al, reported results from a cohort of 722 male CHD patients showing that a light or moderate physical activity was associated with a lower risk of all-cause mortality(16). These results were limited by a relatively short follow-up of 5 years and were difficult to interpret, as physical activity was classified by type (walking, gardening, and sporting activity) without numerical quantification of energy expenditure. In 2006, another survey including 1,045 subjects with reported CHD, with a 9-year follow-up, outlined the inverse graded relation between physical activity and all-cause mortality(17). In this study, energy expenditure was quantified and the results were consistent for various strata of the cohort (sex, age, comorbid conditions...). However, this study focused on elderly patients (over 65) and adjustment in multivariate analysis does not include important variables such as left ventricular function and cardio-vascular risk factors. In 2008, Appullan et al, published data from the CASS Registry with a median follow-up of 14.7 years(18). Similarly to our study, their results demonstrated an independent correlation between the level of physical activity and long term mortality. These data are of interest as they derived from a very large population of 14,021 individuals. However, physical activity was not assessed accurately and was simply graded into four categories (sedentary, mild, moderate and strenuous). Moreover, these patients were recruited in the 1970s and 1980s and the advances made in the treatment of CHD since then are likely to attenuate the prognosis impact of physical activity. At last, the adjustment on potential confounding factors in $\mathrm{CHD}$ seems here again incomplete, as left ventricular function is missing. More recently, two large studies addressed the question of physical activity in CHD. In 2017, Stewart et al analyzed the data of a cohort of 15,486 patients from 39 countries with stable CHD followed over 3.7 years(19) included in the STABILITY (Stabilization of Atherosclerotic Plaque by Initiation of 
Darapladib Therapy) trial. Physical Activity was estimated by a questionnaire that provided a quantitative assessment of physical activity in METS hour per week. This study showed that a higher level of physical activity was independently associated with lower all-cause mortality, especially in patients sedentary at baseline or in high risk patients, as estimated by the $\mathrm{ABC}-\mathrm{CHD}$ risk score. These results are of interest, but the follow-up duration is limited. Moholdt et al published in 2018 a study with 3307 individuals who self-reported to suffer from CHD, with a median follow-up of 15.7 years(20). This work focused on the impact on mortality of physical activity and weight lost. It showed a significant mortality risk reduction associated with sustained physical activity and no mortality risk reduction associated with weight loss. The first limitation of that survey was the semi-quantitative assessment of physical activity (inactive, low activity, high activity). Other limitation is the lack of relevant cardiac data in CHD, such as LVEF, in order to provide a complete adjustment in multivariate analysis. Our study demonstrates the independent association between long term all-cause mortality and physical activity level, consistently with the previous reports listed above, with a long term follow-up, a complete adjustment on potential confounding factors in CHD and a quantitative assessment of energy expenditure.

This association between physical activity and long term all-cause mortality is also observed in our study in patients with reduced ejection fraction, as shown in Figure b. However, the benefit of physical activity on mortality in heart failure patients is still under debate. In 2019 a Cochrane review of 44 clinical trials evaluating exercise-based cardiac rehabilitation for heart failure patients concluded that it reduces short-term overall hospital admission $(16.7 \%$ vs 23.7\% RR=0.70 95\% $\mathrm{Cl}[0.60-0.83])$; however no differences were observed regarding allcause mortality at 1-year follow-up between patients that benefited from cardiac rehabilitation and controls, although a tendency appeared in long term follow-up ( $>1$ year) : $17.2 \%$ vs $19.6 \%, \mathrm{RR}=0.8895 \% \mathrm{Cl}[0.75-1.02](21)$. It is noteworthy that the population this Cochrane review is a combination of patients presenting with different heart failure etiology (not only ischemic), and different levels of LVEF (preserved and reduced LVEF). Moreover, few of the 
studies included in this meta-analysis had a long term follow-up. In 2012, Belardinelli et al published a report with a 10-year follow-up, based on patients with depressed LVEF (mean LVEF $37 \%$ ), $80 \%$ of whom had ischemic etiology: a significant benefit of moderate physical activity on mortality was observed ( $\mathrm{HR}=0.6895 \% \mathrm{CI}[0.30-0.82]$ (22). These data, resulting from a population comparable to the patients with depressed LVEF of our cohort, are consistent with our results.

Our study presents some limitations. First, physical activity level was self-evaluated based on a questionnaire. Although this method is robust, it remains less accurate than direct assessment methods. However, such methods would have been very difficult to set up on such a large cohort and over a long period of time. Indeed our aim was to assess patterns of usual behavior, not to make a punctual measurement of physical activity. Second, we considered physical activity level at baseline and we were not able to take into account potential changes in activity level over time, which could influence the patient prognosis (23). Third, patients in this study were recruited in the early 2000s and the outcomes reflect treatment practices in use at the time. At last, the design of the study, which is monocentric and limited to male patients, could constitute a potential restriction to the generalization of the conclusions. However, the consistency of our results with previous studies - which included male and female patients in different countries - led us to assume that our conclusions remain relevant for all CHD patients.

In conclusion, this study - which combines, for the first time, a long term follow up, a complete adjustment on potential confounding factors in CHD and a quantitative assessment of energy expenditure - demonstrates that the level of physical activity in patients presenting with stable CHD is independently associated with long term all-cause mortality.

\section{Conflict of interest}

None 


\section{References}

1. Task Force M, Montalescot G, Sechtem U, Achenbach S, Andreotti F, Arden C, Budaj A, Bugiardini R, Crea F, Cuisset T, Di Mario C, Ferreira JR, Gersh BJ, Gitt AK, Hulot JS, Marx N, Opie LH, Pfisterer M, Prescott E, Ruschitzka F, Sabate M, Senior R, Taggart DP, van der Wall EE, Vrints CJ, Guidelines ESCCfP, Zamorano JL, Achenbach S, Baumgartner H, Bax JJ, Bueno H, Dean V, Deaton C, Erol C, Fagard R, Ferrari R, Hasdai D, Hoes AW, Kirchhof P, Knuuti J, Kolh P, Lancellotti P, Linhart A, Nihoyannopoulos P, Piepoli MF, Ponikowski P, Sirnes PA, Tamargo JL, Tendera M, Torbicki A, Wijns W, Windecker S, Document R, Knuuti J, Valgimigli M, Bueno H, Claeys MJ, Donner-Banzhoff N, Erol C, Frank H, Funck-Brentano C, Gaemperli O, Gonzalez-Juanatey JR, Hamilos M, Hasdai D, Husted S, James SK, Kervinen K, Kolh P, Kristensen SD, Lancellotti P, Maggioni AP, Piepoli MF, Pries AR, Romeo F, Ryden L, Simoons ML, Sirnes PA, Steg PG, Timmis A, Wijns W, Windecker S, Yildirir A, Zamorano JL. 2013 ESC guidelines on the management of stable coronary artery disease: the Task Force on the management of stable coronary artery disease of the European Society of Cardiology. Eur Heart J 2013;34(38):2949-3003.

2. Fihn SD, Gardin JM, Abrams J, Berra K, Blankenship JC, Dallas AP, Douglas PS, Foody JM, Gerber TC, Hinderliter AL, King SB, 3rd, Kligfield PD, Krumholz HM, Kwong RY, Lim MJ, Linderbaum JA, Mack MJ, Munger MA, Prager RL, Sabik JF, Shaw LJ, Sikkema JD, Smith CR, Jr., Smith SC, Jr., Spertus JA, Williams SV, Anderson JL, American College of Cardiology Foundation/American Heart Association Task F. 2012 ACCF/AHA/ACP/AATS/PCNA/SCAI/STS guideline for the diagnosis and management of patients with stable ischemic heart disease: a report of the American College of Cardiology Foundation/American Heart Association task force on practice guidelines, and the American College of Physicians, American Association for Thoracic Surgery, Preventive Cardiovascular Nurses Association, Society for Cardiovascular Angiography and Interventions, and Society of Thoracic Surgeons. Circulation 2012;126(25):e354-471. 
3. O'Gara PT, Kushner FG, Ascheim DD, Casey DE, Jr., Chung MK, de Lemos JA, Ettinger SM, Fang JC, Fesmire FM, Franklin BA, Granger CB, Krumholz HM, Linderbaum JA, Morrow DA, Newby LK, Ornato JP, Ou N, Radford MJ, Tamis-Holland JE, Tommaso CL, Tracy CM, Woo YJ, Zhao DX, Anderson JL, Jacobs AK, Halperin JL, Albert NM, Brindis RG, Creager MA, DeMets D, Guyton RA, Hochman JS, Kovacs RJ, Kushner FG, Ohman EM, Stevenson WG, Yancy CW, American College of Cardiology Foundation/American Heart Association Task Force on Practice G. 2013 ACCF/AHA guideline for the management of ST-elevation myocardial infarction: a report of the American College of Cardiology Foundation/American Heart Association Task Force on Practice Guidelines. Circulation 2013;127(4):e362-425.

4. Anderson L, Oldridge N, Thompson DR, Zwisler AD, Rees K, Martin N, Taylor RS. Exercise-Based Cardiac Rehabilitation for Coronary Heart Disease: Cochrane Systematic Review and Meta-Analysis. J Am Coll Cardiol 2016;67(1):1-12.

5. Pouche M, Ruidavets JB, Ferrieres J, lliou MC, Douard H, Lorgis L, Carrie D, Brunel P, Simon T, Bataille V, Danchin N. Cardiac rehabilitation and 5-year mortality after acute coronary syndromes: The 2005 French FAST-MI study. Arch Cardiovasc Dis 2016;109(3):178-187.

6. Grau M, Bongard V, Fito M, Ruidavets JB, Sala J, Taraszkiewicz D, Masia R, Galinier M, Subirana I, Carrie D, Vila J, Marrugat J, Ferrieres J, Regicor Gl. Prevalence of cardiovascular risk factors in men with stable coronary heart disease in France and Spain. Arch Cardiovasc Dis 2010;103(2):80-89.

7. Bouisset F, Bongard V, Ruidavets JB, Hascoet S, Taraszkiewicz D, Roncalli J, Carrie D, Galinier M, Elbaz M, Ferrieres J. Prognostic usefulness of clinical and subclinical peripheral arterial disease in men with stable coronary heart disease. Am J Cardiol 2012;110(2):197-202.

8. Genoux A, Ruidavets JB, Ferrieres J, Combes G, Lichtenstein L, Pons V, Laffargue M, Taraszkiewicz D, Carrie D, Elbaz M, Perret B, Martinez LO. Serum IF1 concentration is 
independently associated to HDL levels and to coronary heart disease: the GENES study. $J$ Lipid Res 2013;54(9):2550-2558.

9. Verdier C, Ruidavets JB, Bongard V, Taraszkiewicz D, Martinez LO, Elbaz M, Ferrieres J, Perret B. Association of hepatic lipase -514T allele with coronary artery disease and ankle-brachial index, dependence on the lipoprotein phenotype: the GENES study. PLoS One 2013;8(7):e67805.

10. Genoux A, Lichtenstein L, Ferrieres J, Duparc T, Bongard V, Vervueren PL, Combes G, Taraszkiewicz D, Elbaz M, Galinier M, Nassar B, Ruidavets JB, Perret B, Martinez LO. Serum levels of mitochondrial inhibitory factor 1 are independently associated with long-term prognosis in coronary artery disease: the GENES Study. BMC Med 2016;14(1):125.

11. Martinez LO, Genoux A, Ferrieres J, Duparc T, Perret B. Serum inhibitory factor 1, high-density lipoprotein and cardiovascular diseases. Curr Opin Lipidol 2017;28(4):337-346.

12. Verdier C, Ruidavets JB, Genoux A, Combes G, Bongard V, Taraszkiewicz D, Galinier M, Elbaz M, Ferrieres J, Martinez LO, Perret B. Common p2y13 polymorphisms are associated with plasma inhibitory factor 1 and lipoprotein(a) concentrations, heart rate and body fat mass: The GENES study. Arch Cardiovasc Dis 2019;112(2):124-134.

13. Gensini GG. A more meaningful scoring system for determining the severity of coronary heart disease. Am J Cardiol 1983;51(3):606.

14. Roeykens J, Rogers R, Meeusen R, Magnus L, Borms J, de Meirleir K. Validity and reliability in a Flemish population of the WHO-MONICA Optional Study of Physical Activity Questionnaire. Med Sci Sports Exerc 1998;30(7):1071-1075.

15. Pereira MA, FitzerGerald SJ, Gregg EW, Joswiak ML, Ryan WJ, Suminski RR, Utter AC, Zmuda JM. A collection of Physical Activity Questionnaires for health-related research. Med Sci Sports Exerc 1997;29(6 Suppl):S1-205.

16. Wannamethee SG, Shaper AG, Walker M. Physical activity and mortality in older men with diagnosed coronary heart disease. Circulation 2000;102(12):1358-1363.

17. Janssen I, Jolliffe CJ. Influence of physical activity on mortality in elderly with coronary artery disease. Med Sci Sports Exerc 2006;38(3):418-427. 
18. Apullan FJ, Bourassa MG, Tardif JC, Fortier A, Gayda M, Nigam A. Usefulness of self-reported leisure-time physical activity to predict long-term survival in patients with coronary heart disease. Am J Cardiol 2008;102(4):375-379.

19. Stewart RAH, Held C, Hadziosmanovic N, Armstrong PW, Cannon CP, Granger CB, Hagstrom E, Hochman JS, Koenig W, Lonn E, Nicolau JC, Steg PG, Vedin O, Wallentin L, White HD, Investigators S. Physical Activity and Mortality in Patients With Stable Coronary Heart Disease. J Am Coll Cardiol 2017;70(14):1689-1700.

20. Moholdt T, Lavie CJ, Nauman J. Sustained Physical Activity, Not Weight Loss, Associated With Improved Survival in Coronary Heart Disease. J Am Coll Cardiol 2018;71(10):1094-1101.

21. Long L, Mordi IR, Bridges C, Sagar VA, Davies EJ, Coats AJ, Dalal H, Rees K, Singh SJ, Taylor RS. Exercise-based cardiac rehabilitation for adults with heart failure. Cochrane Database Syst Rev 2019;1:CD003331.

22. Belardinelli R, Georgiou D, Cianci G, Purcaro A. 10-year exercise training in chronic heart failure: a randomized controlled trial. J Am Coll Cardiol 2012;60(16):1521-1528.

23. Lahtinen M, Toukola T, Junttila MJ, Piira OP, Lepojarvi S, Kaariainen M, Huikuri HV, Tulppo MP, Kiviniemi AM. Effect of Changes in Physical Activity on Risk for Cardiac Death in Patients With Coronary Artery Disease. Am J Cardiol 2018;121(2):143-148. 


\section{Figure legends}

Figure a: Cumulative survival according to physical activity level

Figure b: Cumulative survival according to physical activity level and level of Left Ventricular Ejection Fraction 
Tables

Table 1: Description of the population according to the level of physical activity

Table 2 : Multivariable Cox regression or the association between levels (tertiles) of physical activity and all-cause death.

Table 3 : Multivariable Cox regression determining independent predictors of all-cause death. 

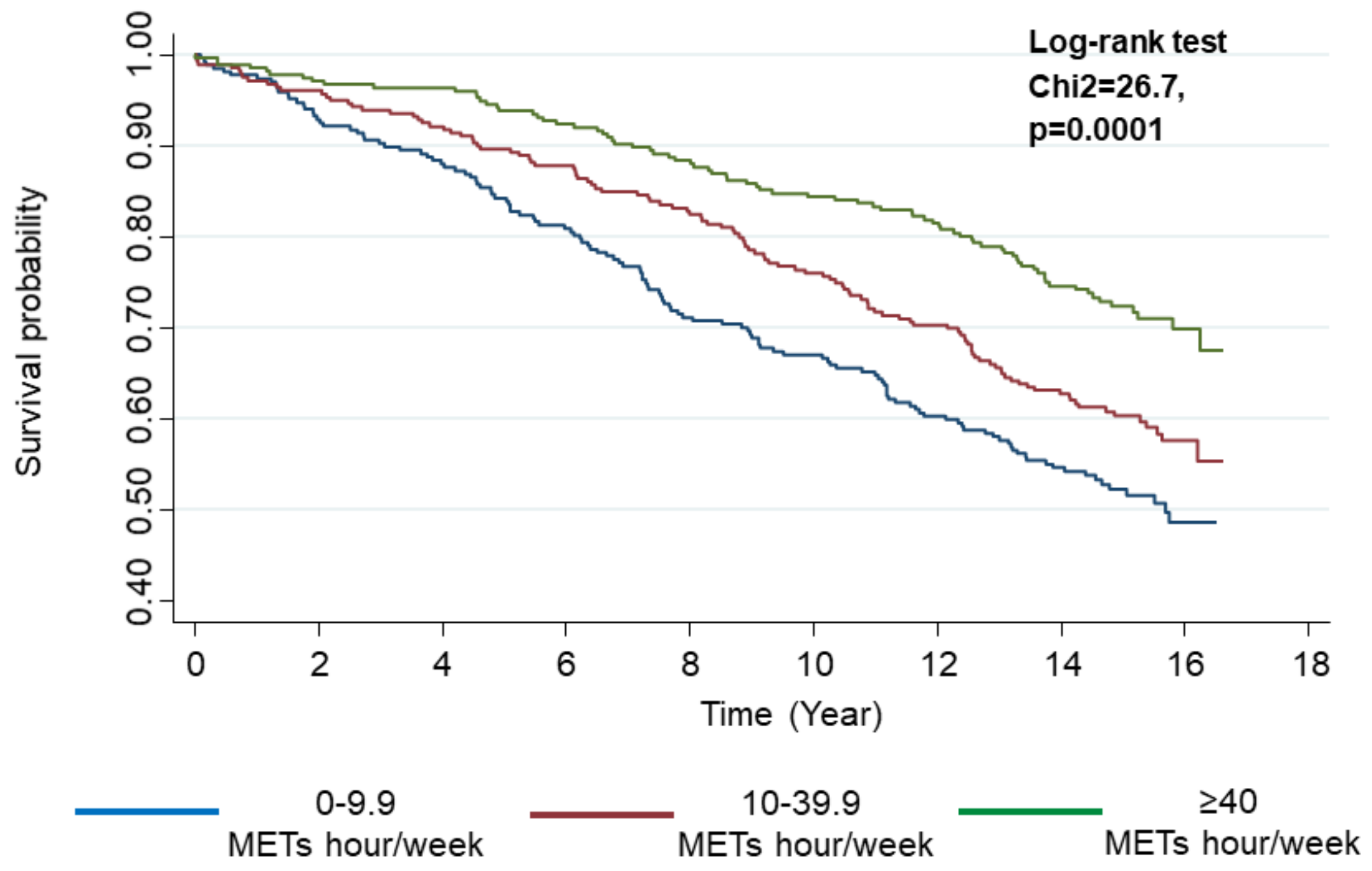
Patients with LVEF $<50 \%$

$n=221$

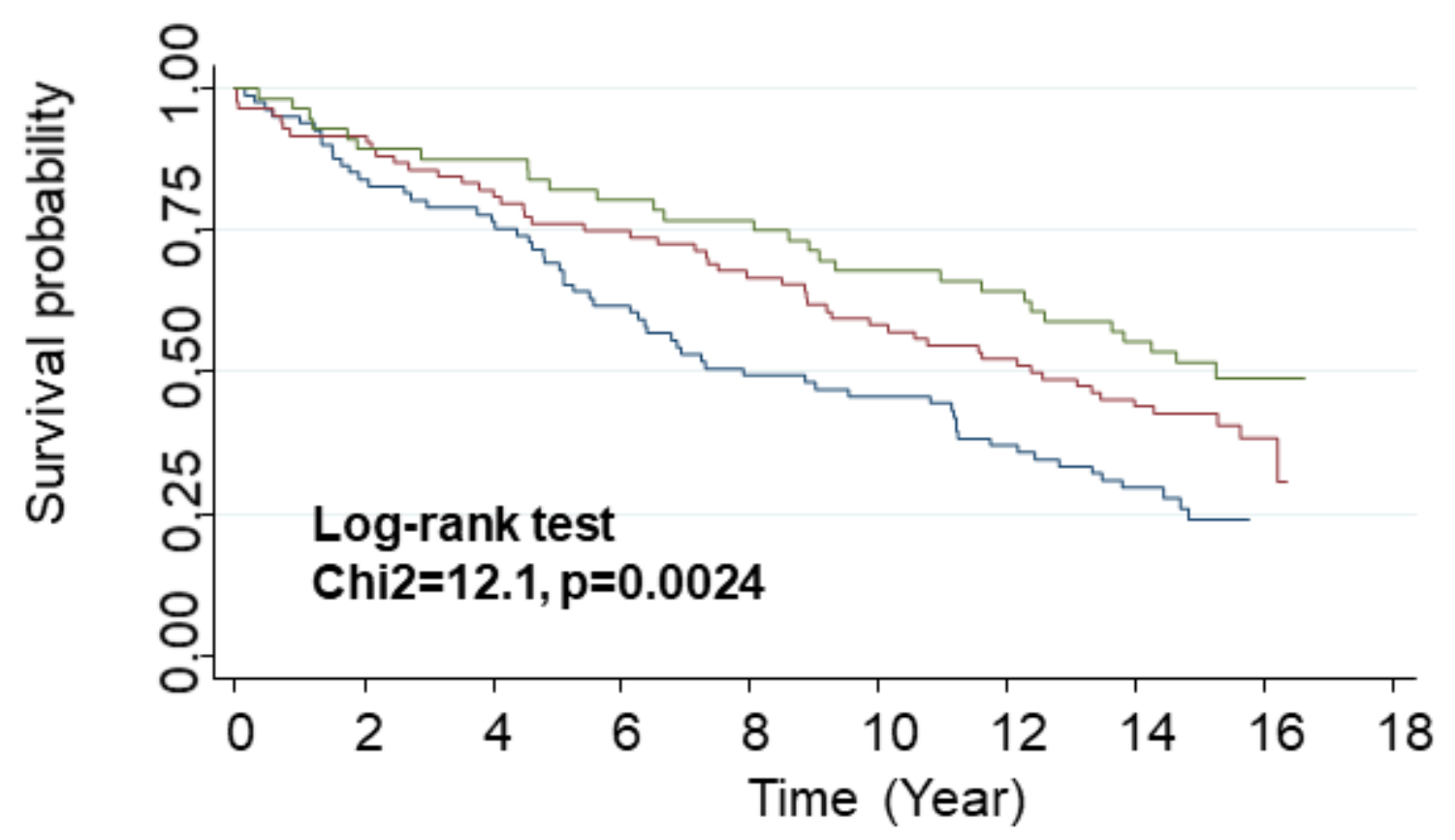

Patients with LVEF $\geq \mathbf{5 0} \%$

$n=601$

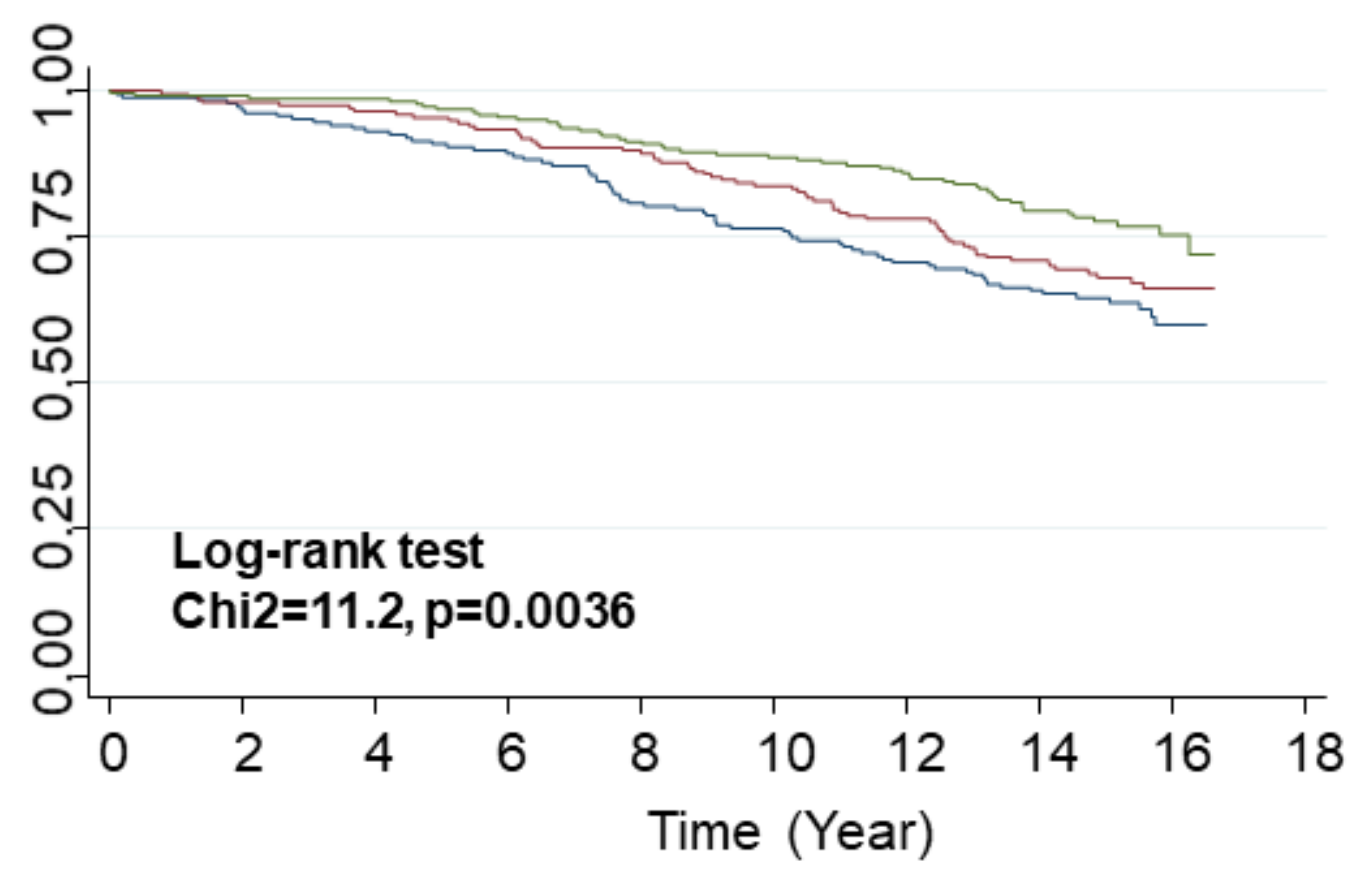

10-39.9

METs hour/week $\geq 40$

METs hour/week 


\begin{tabular}{|c|c|c|c|c|c|}
\hline Variables & All $(n=822)$ & $\begin{array}{l}\text { 0-9.9 METs hour } \\
\text { per week }(n=267)\end{array}$ & $\begin{array}{l}\text { 10-39.9 METs hour } \\
\text { per week }(n=279)\end{array}$ & $\begin{array}{l}\geq 40 \text { METs hour per } \\
\text { week }(n=276)\end{array}$ & $\mathbf{p}$ \\
\hline Age (years) & $60.1( \pm 8.1)$ & $62.9( \pm 7.5)$ & $61.3( \pm 7.5)$ & $56.1( \pm 7.7)$ & 0.001 \\
\hline Waist circumference (cm) & $98.9( \pm 10.9)$ & $100.4( \pm 11)$ & $100( \pm 11.2)$ & $96.2( \pm 10)$ & 0.001 \\
\hline Body mass index $\left(\mathrm{kg} / \mathrm{m}^{2}\right)$ & $27.4( \pm 4.0)$ & $27.6( \pm 4.1)$ & $27.7( \pm 4.2)$ & $26.9( \pm 3.7)$ & 0.037 \\
\hline Heart rate (beat/min) & $64.1( \pm 12.1)$ & $65.2( \pm 12.5)$ & $64.5( \pm 12.3)$ & $62.7( \pm 11.5)$ & 0.05 \\
\hline High Blood Pressure (\%) & $563(68.5 \%)$ & $197(73.8 \%)$ & $194(69.5 \%)$ & $172(62.3 \%)$ & 0.014 \\
\hline Systolic blood pressure (mmHg) & $139.5( \pm 20.6)$ & $141.5( \pm 20.5)$ & $139( \pm 20.9)$ & $138.1( \pm 20.4)$ & 0.15 \\
\hline Diastolic blood pressure $(\mathrm{mmHg})$ & $84.6( \pm 10.7)$ & $84.7( \pm 10.2)$ & $84.2( \pm 10.9)$ & $85.1( \pm 11.0)$ & 0.64 \\
\hline Serum Total Cholesterol (mg/dl) & $201( \pm 44)$ & $199( \pm 43)$ & $198( \pm 43)$ & $207( \pm 44)$ & 0.014 \\
\hline HDLc (mg/dl) & $43( \pm 12)$ & $42( \pm 12)$ & $43( \pm 12)$ & $44( \pm 13)$ & 0.25 \\
\hline LDLc (mg/dl) & $125( \pm 39)$ & $124( \pm 38)$ & $122( \pm 38)$ & $130( \pm 40)$ & 0.06 \\
\hline Triglycerides (mg/dl) & $170( \pm 99)$ & $166( \pm 91)$ & $167( \pm 95)$ & $177( \pm 110)$ & $0.46^{*}$ \\
\hline Dyslipidemia & $597(72.7 \%)$ & $178(66.9 \%)$ & $213(76.6 \%)$ & $206(74.9 \%)$ & 0.026 \\
\hline Diabetes mellitus & $243(29.6 \%)$ & $84(31.8 \%)$ & $90(32.5 \%)$ & $69(25.3 \%)$ & 0.13 \\
\hline Smoking status & & & & & 0.011 \\
\hline Non-smoker & $143(17.4 \%)$ & $50(18.7 \%)$ & $49(17.6 \%)$ & 44 (15.9\%) & \\
\hline
\end{tabular}




\begin{tabular}{|c|c|c|c|c|c|}
\hline Former smoker & $516(62.8 \%)$ & $168(62.9 \%)$ & $189(67.7 \%)$ & $159(57.6 \%)$ & \\
\hline Current smoker & $163(19.8 \%)$ & $49(18.4 \%)$ & $42(14.7 \%)$ & $73(26.5 \%)$ & \\
\hline hs-CRP (mg/L) & $12.9( \pm 21.9)$ & $15( \pm 23.7)$ & $13.5( \pm 25.1)$ & $10.4( \pm 15.5)$ & $0.015^{\star}$ \\
\hline Gensini score & $46.7( \pm 40.1)$ & $51.2( \pm 43.7)$ & $50.1( \pm 37.6)$ & $38.6( \pm 37.8)$ & 0.001 \\
\hline Coronary history & & & & & $<0.001$ \\
\hline Previous myocardial infarction & $436(53.2 \%)$ & $134(50.2 \%)$ & $173(62.0 \%)$ & $129(47.1 \%)$ & \\
\hline $\begin{array}{l}\text { Previous revascularization in } \\
\text { stable context }\end{array}$ & $274(33.4 \%)$ & $90(33.7 \%)$ & $85(30.5 \%)$ & $99(36.1 \%)$ & \\
\hline $\begin{array}{l}\text { CHD treated medically, without } \\
\text { revascularization }\end{array}$ & $110(13.4 \%)$ & $43(16.1 \%)$ & $21(7.5 \%)$ & $46(16.8 \%)$ & \\
\hline Alcohol consumption (g/day) & $28.5( \pm 32.0)$ & $28.7( \pm 35.7)$ & $28( \pm 29)$ & $29( \pm 31.3)$ & 0.65 \\
\hline Duration of disease (months) & $42.4( \pm 65.9)$ & $43.5( \pm 68.8)$ & $48.9( \pm 68.6)$ & $34.7( \pm 59.5)$ & 0.038 \\
\hline Ankle-arm index $\leq 0.9$ & $274(33.3 \%)$ & $102(38.2 \%)$ & $101(36.2 \%)$ & $71(25.7 \%)$ & 0.004 \\
\hline $\begin{array}{l}\text { Left Ventricular Ejection Fraction } \\
<50 \%\end{array}$ & $221(26.9 \%)$ & $81(30.3 \%)$ & $84(30.1 \%)$ & $56(20.3 \%)$ & 0.01 \\
\hline $\begin{array}{l}\text { Left Ventricular Ejection Fraction } \\
(\%)\end{array}$ & $0.53( \pm 0.14)$ & $0.51( \pm 0.15)$ & $0.52( \pm 0.14)$ & $0.55( \pm 0.12)$ & $0.0068^{*}$ \\
\hline Dyslipidemia & $525(63.9 \%)$ & $161(60.2 \%)$ & $191(68.5 \%)$ & $173(62.7 \%)$ & 0.13 \\
\hline Diabetes & $199(24.2 \%)$ & $71(26.6 \%)$ & $78(28.0 \%)$ & $50(18.1 \%)$ & 0.014 \\
\hline
\end{tabular}




$\begin{array}{llllll}\text { Hypertension } & 362(44.0 \%) & 134(50.2 \%) & 130(46.6 \%) & 98(35.5 \%) & 0.002 \\ \text { Death } & 324(39.4 \%) & 130(48.7 \%) & 115(41.2 \%) & 79(26.6 \%) & <0.0001\end{array}$

Table 1: Description of the population according to the level of physical activity

hs-CRP: high sensitivity C-Reactive Protein; HDL: High Density Lipoprotein; LDL: Low density Lipoprotein

*: analyses performed on log-transformed data 
0-9.9 ( $n=267)$

$10-39.9(n=279)$

HR $(95 \% \mathrm{Cl})$, p

$0.76(0.60: 0.98), p=0.033$

$0.79(0.61: 1.03), p=0.08$

$0.71(0.53: 0.96), p=0.025$

Table 2 : Multivariable Cox regression or the association between levels (tertiles) of physical activity and all-cause of death.

*Adjustment for age, dyslipidemia, smoking status, diabetes, high blood pressure, waist circumference, left ventricular ejection fraction, Gensini score, heart rate, ankle-brachial index and duration of disease 


\begin{tabular}{|c|c|c|c|c|}
\hline \multirow[b]{2}{*}{ Variables } & \multicolumn{2}{|c|}{ Non-adjusted } & \multicolumn{2}{|c|}{ Multivariate adjusted } \\
\hline & $\mathrm{HR}(95 \% \mathrm{Cl})$ & $\mathbf{p}$ & HR $(95 \% \mathrm{Cl})$ & $\mathbf{p}$ \\
\hline Age (years) & $\begin{array}{c}1.05 \\
(1.04 ; 1.07)\end{array}$ & 0.001 & $\begin{array}{c}1.04 \\
(1.02 ; 1.06)\end{array}$ & 0.001 \\
\hline Waist circumference $(\mathrm{cm})$ & $\begin{array}{c}1.02 \\
(1.01 ; 1.03)\end{array}$ & 0.001 & $\begin{array}{c}1.01 \\
(1.002 ; 1.02)\end{array}$ & 0.013 \\
\hline Heart rate (beat/mn) & $\begin{array}{c}1.02 \\
(1.01 ; 1.03)\end{array}$ & 0.001 & $\begin{array}{c}1.01 \\
(1.004 ; 1.02)\end{array}$ & 0.005 \\
\hline Current smoker & $\begin{array}{c}1.34 \\
(0.93 ; 1.94)\end{array}$ & 0.13 & $\begin{array}{c}2.21 \\
(1.48 ; 3.31)\end{array}$ & 0.001 \\
\hline Former smoker & $\begin{array}{c}1.33 \\
(0.97 ; 1.82)\end{array}$ & 0.07 & $\begin{array}{c}1.37 \\
(0.99 ; 1.89)\end{array}$ & 0.06 \\
\hline Gensini score & $\begin{array}{c}1.37 \\
(1.21 ; 1.56)\end{array}$ & 0.001 & $\begin{array}{c}1.12 \\
(0.98 ; 1.29)\end{array}$ & 0.09 \\
\hline Length of disease (months) & $\begin{array}{c}1.05 \\
(1.03 ; 1.07)\end{array}$ & 0.001 & $\begin{array}{c}1.03 \\
(1.01 ; 1.05)\end{array}$ & 0.001 \\
\hline Ankle-arm index $\leq 0.9$ & $\begin{array}{c}1.76 \\
(1.41 ; 2.19)\end{array}$ & 0.001 & $\begin{array}{c}1.32 \\
(1.05 ; 1.66)\end{array}$ & 0.017 \\
\hline $\begin{array}{l}\text { Left Ventricular Ejection } \\
\text { Fraction }<50 \%\end{array}$ & $\begin{array}{c}2.83 \\
(2.27 ; 3.52)\end{array}$ & 0.001 & $\begin{array}{c}2.17 \\
(1.72 ; 2.75)\end{array}$ & 0.001 \\
\hline Dyslipidemia & $\begin{array}{c}0.69 \\
(0.55 ; 0.86)\end{array}$ & 0.001 & $\begin{array}{c}0.70 \\
(0.55 ; 0.88)\end{array}$ & 0.001 \\
\hline Diabetes mellitus & $\begin{array}{c}1.94 \\
(1.54 ; 2.44)\end{array}$ & 0.001 & $\begin{array}{c}1.39 \\
(1.08 ; 1.78)\end{array}$ & 0.009 \\
\hline Hypertension & $\begin{array}{c}1.20 \\
(0.96 ; 1.49)\end{array}$ & 0.10 & $\begin{array}{c}1.08 \\
(0.86 ; 1.36)\end{array}$ & 0.50 \\
\hline $\begin{array}{l}\text { Physical activity (increase } \\
\text { of } 10 \text { METs hour per week) }\end{array}$ & $\begin{array}{c}0.91 \\
(0.88 ; 0.94)\end{array}$ & 0.001 & $\begin{array}{c}0.95 \\
(0.92 ; 0.98)\end{array}$ & 0.002 \\
\hline
\end{tabular}

Table 3 : Multivariable Cox regression determining independent predictors of all-cause death 